\title{
Editorial
}

\section{The Crisis that Changed Everything: Reflections of and Reflections on COVID-19}

During the course of 2020 there is barely an aspect of everyday life that has not been affected by the COVID-19 pandemic in one way or another, if there are any at all. The realms of crime, criminal law, criminal justice and criminology are no exception. One rough and ready indicator is that, as early as 12 April 2020, a chapter headed the 'Impact of the COVID-19 pandemic on crime' was initiated on Wikipedia. ${ }^{1}$ Another is that a perfunctory internet search using a term such as "crime and COVID-19" or "criminal justice and COVID-19" yields millions of results in an instant. Admittedly, this evidence is superficial in nature but it is sufficient to indicate that one of the legacies of the pandemic will be to establish a new focus of study that is concerned with its impact on the criminal law field (broadly defined). That supposition is reinforced by the fact that its cultural, economic, environmental, political and social consequences, all facets of life that intersect strongly with criminal law, are of such magnitude that they will ricochet long into the future. Moreover, this will be the case irrespective of whether there is rapid success in the quest to eradicate the virus itself.

Our Journal is most unlikely to remain immune from these developments as they have many aspects that fit squarely within its aims and scope. Merely in outline, the COVID-19 crisis has prompted a range of relevant responses from the principal European organs of governance; i.e. the EU and the Council of Europe, and their agencies and institutions; it is affecting the manifestations and representations of crime across Europe, as well as their handling; and 
there is extensive potential for comparative study of these issues as between different European states and for their exploration in a manner that contributes to criminological debate in Europe.

Taken together, these considerations make it highly pertinent to dedicate the final editorial of 2020 to the topic of the pandemic. More specifically, it will illustrate some of the ways in which the pandemic has been affecting matters that fall within the Journal's subject matter, using the above headings as an analytical framework. While not amounting to a systematic review, this will provide a preliminary indication of the scale and complexity of the emerging research field. It will conclude by offering some brief critical reflections on whether the COVID-19 crisis really has "changed everything", or is likely to do so.

\section{Manifestations or Representations of Crime in Europe and/or its Impact}

Reports of the virus being linked to crime started to surface remarkably quickly once there were confirmed outbreaks of COVID-19 in Europe, and were becoming an established phenomenon by March 2020. At the street crime level perhaps the most striking manifestations have been instances in which the virus and/or the fear of it has been harnessed opportunistically as a means of perpetrating acts of inter-personal violence. For example, through spitting or engaging in other forms of conduct that are liable to facilitate transmission, or threatening to behave in such ways. In the most serious cases it has been alleged that episodes of what might be termed "COVID-19 assault" have not only caused victims to contract the disease but that doing so has resulted in their deaths. ${ }^{2}$

The rapid emergence of this novel category of offending has presented challenges to law enforcement authorities of at least two kinds. First, there is the question of whether a specially tailored response is needed to address the "weaponisation" of the virus and, if so, what that response should be. In the Netherlands at least, it has been answered in the affirmative. By early April a fast track procedure ("supersnelrecht") was being used to bring perpetrators to court. Furthermore, the District Court of Rotterdam had identified five categories of COVID-19 related offences and specified whether and how the fact that the virus was somehow involved should be

2 See, for example, M. Weaver and V. Dodd, 'UK rail worker dies of coronavirus after being spat at while on duty', Guardian, 12 May 2020 (https://www.theguardian.com/ uk-news/2020/may/12/uk-rail-worker-dies-coronavirus-spat-belly-mujinga). 
taken into account in sentencing. ${ }^{3}$ There may be similar examples in other European jurisdictions.

Second, in common with other front line workers, police officers, prison officers and certain other criminal justice professionals are at elevated risk of exposure to COVID-19 assault. Plainly, therefore, the risk of becoming a victim of such an offence is not distributed evenly across the population but certain groups are disproportionately affected compared with others. Furthermore, once race, class and gender are factored into the picture, the differences are all the more stark, reflecting broader discrepancies in risk of exposure to the virus. ${ }^{4}$ Nor is this the only way in which the circumstances of the pandemic have led to an increased risk of inter-personal violence for those who are already subject to structural disadvantage. Another example is provided by reports that those with Chinese and other south east asian ethnic heritage have been subject to hate crimes due to the geographical origins of the virus in Wuhan.

Regarding other categories of crime, it is not so much the virus itself that has opened up opportunities for offending but aspects of the response to it. A prime example is counterfeiting and fraud relating to medical and hygiene products that are intrinsic to efforts to combat COVID-19 (or that are perceived or rumoured to be); that is, face masks and other types of personal protective equipment ("PPE"); prophylactic and therapeutic medicines; PCR, antigen and antibody tests; sanitisers and cleaning products; and certain nutritional supplements (e.g. vitamin D). ${ }^{5}$ For all too obvious reasons the advent of the pandemic sparked a ravenous demand for these commodities, leading to well-documented global shortages in supply, especially during the early months. Not only did this foment the development of illicit markets but an additional stimulus was provided by governments and other public authorities in the form of extremely lucrative, large scale public procurement contracts.

3 D. de Vocht, 'The many effects of COVID-19 on the criminal justice system', Maastricht University blog, 2 April 2020, available at: https://www.maastrichtuniversity.nl/ blog/2020/o4/many-effects-covid-19-criminal-justice-system (henceforth "de Vocht, 2 April $\left.2020^{\prime \prime}\right)$.

4 I. Sample, 'Meta-study: Researchers detail scale of BAME Covid risk', Guardian, 13 November 2020, available at: https://www.theguardian.com/world/2020/nov/12/ black-and-asian-people-at-greater-risk-of-getting-covid-meta-study-finds.

5 It is already forecast that once vaccines become available, they will also be subject to counterfeiting and fraud: Europol, Viral Marketing: Counterfeits, Substandard Goods and Intellectual Property Crime in the COVID-19 Pandemic, 17 April 2020, available at: https://www.europol.europa.eu/publications-documents/viral-marketing-counterfeitssubstandard-goods-and-intellectual-property-crime-in-covid-19-pandemic. 
There is already evidence to suggest that these have acted as a magnet for those engaged in cross-border organised crime.

To provide one example, in April 2020, Europol reported that it had helped to foil an attempt to sell non-existent face masks to the German health authorities. In furtherance of the scam the perpetrators involved an Irish middleman, created fake websites for Spanish and Dutch companies and compromised legitimate email addresses. In total, the contract was worth $€_{15}$ million. At the time that the fraud came to light over $€ 2$ million of the money had been paid and deposited in British and Irish banks, preparatory to its transfer to an account in Nigeria. ${ }^{6}$

Separately from the medical and sanitary arena, the imposition of lockdown and other restrictions in order to arrest the spread of the virus has also inspired fraud and counterfeiting. The target here has been permits or other documentation that have been required in some jurisdictions in order to participate in activities that would otherwise be prohibited. ${ }^{7}$ Fraud and counterfeiting, though, represent the tip of the iceberg as lockdown conditions have also been linked to many other types of offending.

Two that have received particular attention are domestic violence against women, children and members of the LGBTQ+ community ${ }^{8}$ and cybercrime: cyber-fraud; hacking; infrastructure attack; malware and ransomware attack; online scams; phishing and so on. ${ }^{9}$ The reasons are not hard to discern. In the first case the problem is that obliging people to stay at home as far as possible means that victims and potential victims are compelled to remain in close proximity with their abuser. Not only is this dangerous but accessing

$6 \quad$ 'Corona crimes: Multi-million face mask scam foiled by police across Europe', Europol Press Release, 14 April 2020 (https://www.europol.europa.eu/newsroom/news/corona-crimesmulti-million-face-mask-scam-foiled-police-across-europe). Reflecting the complexity of the operation, the investigation also involved financial and other authorities in Germany, Ireland, the Netherlands and the United Kingdom as well as Interpol.

7 See, for example, France, which under its second lockdown it is mandatory to complete and carry paperwork to justify journeys from home: https:/www.bbc.co.uk/news/ explainers-53640249.

8 See, for example, 'Covid-19: General Information', Victim Support Europe, available at: https://victimsupport.eu/covid-19-information/.

9 See, for example, Europol, Pandemic Profiteering: How Criminals Exploit the Covid-19 Crisis, 27 March 2020, available at: https://www.europol.europa.eu/publications-documents/ pandemic-profiteering-how-criminals-exploit-covid-19-crisis); Cybercrime and Covid-19, Council of Europe News, 27 March 2020 (https://www.coe.int/en/web/cybercrime/-/ cybercrime-and-covid-19). 
help and support is exceptionally difficult. ${ }^{10}$ In the second, the abrupt and extensive switch to online methods of working that has accompanied lockdowns has created an environment that is ripe for exploitation by those with malicious motives. It is therefore not a surprise that law enforcement and other agencies began to warn of vulnerability to cybercrime from an early point.

Moving beyond these high profile areas, other forms of offending that have been linked to the imposition of lockdown conditions include environmental crimes and crimes against wildlife; ${ }^{11}$ organised property crime; ${ }^{12}$ certain sorts of sexual offences; ${ }^{13}$ and terrorism. ${ }^{14}$ In addition, Europol has published assessments of the impact of the COVID-19 crisis on serious and organised crime $^{15}$ and, in conjunction with the European Monitoring Centre for Drugs and Drug Addiction ["EMCDDA"], on drug markets. ${ }^{16}$ These analyses suggest that the arrival of the pandemic will have been treated as an opportunity for gain, to be exploited by adapting strategies and methods of operation and through diversification in response to the economic consequences of

10 See further 'Covid-19: General Information', Victim Support Europe.

11 Deutsche Welle Akademie, 'Wildlife poaching during CV-19 lockdown', 26 June 2020, available at https://www.dw.com/en/europes-raptors-and-fish-hit-bypoaching-under-lockdown/a-53913328.

Europol, Pandemic Profiteering: How Criminals Exploit the Covid-19 Crisis, 27 March 2020; Covid-19: General Information, Victim Support Europe, available at: https://victimsupport. eu/covid-19-information/.

13 'Exploiting isolation: Sexual predators increasingly targeting children during Covid pandemic', Europol Press Release, 19 June 2020, available at: https://www.europol.europa. eu/newsroom/news/exploiting-isolation-sexual-predators-increasingly-targeting-childrenduring-covid-pandemic.

J. Grierson, 'Counter-terror chief warns of extremism rise in pandemic, Guardian, 24 September 2020, available at: https:/www.theguardian.com/uk-news/2020/sep/23/ children-interested-in-extremism-covid-says-neil-basu-counter-terrorism-officer.

Europol, Beyond the Pandemic: How Covid-19 Will Shape the Serious and Organised Crime Landscape in the EU, 30 April 2020, available at: https://www.europol.europa. eu/publications-documents/beyond-pandemic-how-covid-19-will-shape-serious-andorganised-crime-landscape-in-eu.

16 Covid-19 and Drugs: Drug Supply via Darknet Markets, EMCDDA Special Report, May 2020, available at: https://www.emcdda.europa.eu/system/files/publications/13042/EMCDDAreport_COVID19-darknet-final.pdf; EMCDDA and Europol, Drug Markets: Impact of Covid-19, May 2020, available at: https://www.europol.europa.eu/newsroom/news/ eu-drug-markets-impact-of-covid-19. 
the crisis. Moreover, it is forecast that this is likely to prove the case into the mid and long-terms. ${ }^{17}$

\section{Comparison between the Legislation, Policies or Practices in European States}

Where criminal legislation, policies and practices are concerned, two areas stand out as candidates for comparative analysis. First, there is the introduction by most European states of emergency lockdown measures that are designed to stem community transmission of the virus among the population at large. In order to promote compliance, these have often been accompanied by the creation of dedicated criminal offences, backed by significant sanctions. In Spain, for example, the lockdown was ordered by means of a royal decree that authorised the imposition of fines of at least $€$ 1oo for relatively minor infringements. For more serious offences fines of $€ 600$ to $€ 30,000$ could be imposed or, more draconian still, prison sentences of up to four years in some circumstances. ${ }^{18}$

Delving beneath this general commonality in response, the detailed content and scope of measures has varied, as has the approach to enforcement. For instance, the lockdown regimes in Italy and Spain have been materially stricter than those in England, Germany and the Netherlands, which have been relatively more liberal..$^{19}$ To some extent variations will have been influenced by the local severity of the pandemic and capacity of health services to cope but that is not the only relevant consideration. The most prominent example of a state that has taken a different tack is Sweden, which has elected instead to rely on a voluntary approach towards achieving physical distancing. ${ }^{20}$ Its example points to the fact that other factors have also been relevant, including cultural differences in attitude and policy towards the use of criminal law regulation and matters of policing. Therefore, there are issues here that are worthy of comparative investigation.

\footnotetext{
17 Europol, Beyond the Pandemic: How Covid-19 Will Shape the Serious and Organised Crime Landscape in the $E U$, 30 April 2020.

18 L. Dollimore, 'Fines of up to €6оo,ooo for disobeying coronavirus lockdown in Spain', The Olive Press, 16 March 2020, https://www.theolivepress.es/spain-news/2020/03/16/ fines-of-up-to-e6ooooo-for-disobeying-coronavirus-lockdown-in-spain/. voluntary approach towards achieving physical distancing: https:/www.bbc.co.uk/news/ explainers-53640249. 
The second such field concerns the impact of the pandemic on criminal justice systems, including criminal justice and punishment agencies and institutions. Here the fundamental challenge for European authorities has been to enable criminal justice systems to function while taking effective steps to curb the spread of the virus in criminal justice and punishment settings. This has not just been a matter of safety but also one of logistics. It is clear from the responses in some jurisdictions that there have been fears that operational effectiveness would be compromised by staff shortages due to sickness. In Ireland, for instance, police recruits were moved to the front line, ${ }^{21}$ other police personnel were redeployed and retired prison officers were placed on call in case they were needed to fill gaps. ${ }^{22}$ More generally, recent months have seen wide-ranging modifications to service delivery and methods of working that have affected all stages of the criminal process, from policing through to prisons, psychiatric detention, ${ }^{23}$ restorative justice ${ }^{24}$ and victim support. ${ }^{25}$ Constraints of space preclude a comprehensive overview in the context of this editorial ${ }^{26}$ but by focusing on trials and on prisons it is possible to convey a sense of what has happened.

Starting then with criminal trials, in the early days of the pandemic, the initial decision in many countries was to suspend proceedings entirely or subject to exceptions for particular categories of case. Jurisdictions where this occurred include Albania, England and Wales, Ireland, Kosovo, Macedonia and

See also North Macedonia, where police personnel were redeployed to the Ministry of Interior with full authority without taking the state exam: Civil Rights Defenders, 'Impact of COVID-19 measures on human rights and criminal justice in Western Balkans and Turkey', 26 May 2020, available at: https://crd.org/2020/05/26/impact-of-covid19-measures-on-human-rights-and-criminal-justice-in-western-balkans-and-turkey/ (henceforth "Civil Rights Defenders, 26 May 2020").

'Information regarding the Justice Sector COVID-19 Plans', Irish Department of Justice and Equality, available at: http://www.justice.ie/en/JELR/Pages/Information_regarding_the_ Justice_Sector_COVID-19_plans (henceforth "Irish Department of Justice and Equality").

23 See, for example, Royal College of Psychiatrists, 'COVID-19: Secure Hospital and Criminal Justice Settings', available at: https://www.rcpsych.ac.uk/about-us/responding-to-covid-19/ responding-to-covid-19-guidance-for-clinicians/community-and-inpatient-services/ secure-hospital-and-criminal-justice-settings?searchTerms=secure\%2ohospitals.

24 See further I. Marder, 'Restorative justice and COVID-19: Responding restoratively during/ to the crisis', European Forum for Restorative Justice, available at: https://www.euforumrj. org/en/restorative-justice-and-covid-19-responding-restoratively-duringto-crisis.

25 See, for example, 'Covid-19: General Information', Victim Support Europe.

26 The Centre for Criminal Justice Studies and Fair Trials are collecting detailed information on the impact of COVID-19 on criminal justice settings across Europe. For further details see: https://www.crimeandjustice.org.uk/tags/coronavirus-prisons-europe and https:// www.fairtrials.org/covidıjustice. 
Turkey. ${ }^{27}$ Subsequently, as the first wave of the pandemic began to subside, courts began to reopen but with adjustments to promote physical distancing, such as restrictions on the number of participants and use of video links and staggered hearings. This has been the case in Ireland, for example. ${ }^{28}$ There has also been a widespread trend across the continent towards the use of remote or virtual proceedings that make use of online technology. Examples include Albania, the Netherlands and Serbia. ${ }^{29}$ The precise details vary from place to place but it is already clear that many important questions arise from these developments, including from a comparative perspective.

To air a few, most straightforwardly, there is the question of the efficacy of the new ways of working. Particularly where resort to digital technology is concerned, has the pandemic acted as an accelerant for positive reforms to criminal proceedings that might otherwise have taken far longer to arrive? And, if so, has its use resulted in valuable insights that are transferable across jurisdictions to improve the quality of criminal justice in Europe as a whole? What impact have these developments had on the right to a fair trial, including on suspects and defendants who are particularly vulnerable? And what about the principle of open justice? Already objections have surfaced that the move towards online and virtual proceedings militates against the ability of the public to witness proceedings. ${ }^{30}$

Turning to prisons, the issue of obvious concern has been that they present such an ideal environment for transmission of the virus, all the more so in view of the prevalence of overcrowding. Bearing in mind that contracting COVID-19 can prove fatal, pretty rapidly, commentators began to observe that its circulation in prisons had the capacity to transform a custodial sentence into a death sentence. ${ }^{31}$ Given that risk of death increases with age and also correlates with certain other factors, such as suffering from certain underlying health conditions or BAME background, the point was of particular pertinence to prisoners

27 Civil Rights Defenders, 26 May 2020; J. Richards, 'How will the justice system withstand the coronavirus pandemic?', Prospect Magazine, 18 March 2020, available at: https://www. prospectmagazine.co.uk/politics/how-will-the-justice-system-withstand-the-coronaviruspandemic-covid-19-outbreak-courts-democracy-law; Irish Department of Justice and Equality.

28 Irish Department of Justice and Equality.

29 Civil Rights Defenders, 26 May 2020; de Vocht, 2 April 2020.

30 O. Bowcott, 'Has coronavirus changed the UK justice system for ever?', Guardian, 24 May 2020, available at: https://www.theguardian.com/law/2020/may/24/ has-the-uk-justice-system-been-changed-for-ever-by-the-coronavirus.

31 J. Grierson, 'COVID-19: Prisoners with health issues 'face death sentences", Guardian, 26 March 2020, available at: https://www.theguardian.com/world/2020/mar/26/ covid-19-uk-prisoners-with-health-issues-face-death-sentences. 
in these cohorts. Moreover, as staff go in and out and prisoners receive visits and may be eligible for temporary release, were the virus to take root in a prison, the effect could be to seed the virus into the surrounding community.

To address these concerns, many European jurisdictions announced emergency early release or temporary release schemes, including Albania, England and Wales, Ireland and Turkey. Demonstrating that they were not entirely toothless, according to an academic evaluation that was published in June 2020 (the SPACE Report), more than 128 , ooo prisoners were released as a preventive measure in 20 Member States of the Council of Europe during the initial months of the pandemic. ${ }^{32}$ Conversely, in North Macedonia, early release was suspended but the execution of short term sentences was temporarily postponed. ${ }^{33}$ Other measures have included the suspension of temporary release and/or prison visits (Ireland, the Netherlands, North Macedonia); the introduction of Skype meetings with families and lawyers (Albania); the quarantining of new prisoners (Ireland, North Macedonia) and segregation of those who are especially vulnerable (Ireland); and restrictions on work and exercise in order to ensure physical distancing (Ireland). ${ }^{34}$

Like those relating to criminal trials, these developments affecting prisons also raise important questions that are susceptible to comparative study. Focusing merely on those measures that have been designed to alleviate prison populations, there is room to compare the factors that influenced those jurisdictions that chose to go down this route with those that did not; to explore the detail of different schemes; and to examine the relative impact of policy choices on prison populations and other matters, such as offending rates. The academic evaluation mentioned above is an early example of such work.

Secondly, where countries have implemented early or temporary release schemes, they have not applied universally. In Ireland, for example, low risk prisoners were selected for temporary release whereas in Turkey political prisoners were excluded from early release. ${ }^{35}$ Further questions therefore arise with regard to the relative impact of particular schemes on different categories of prisoner and how their implementation bears upon the punitiveness of the sentence. Another concern that arises both in the context of developments

M.F. Aebi and M.M. Tiago, 'Prisons and prisoners in pandemic times: An evaluation of the short term impact of COVID-19 on prison populations', Council of Europe/University of Lausanne, 18 June 2020, page 1 (henceforth "Aebi and Tiago, 18 June 2020").

33 Civil Rights Defenders, 26 May 2020.

34 Ibid; de Vocht, 2 April 2020; Irish Department of Justice and Equality.

35 Irish Department of Justice and Equality; Civil Rights Defenders, 26 May 2020. 
in prisons and in relation to criminal trials is the treatment of pre-trial detention. A highly controversial area in any event, it is notable that pre-trial detainees have been explicitly excluded from the scope of some temporary release schemes (Albania, Ireland). ${ }^{36}$ Conversely, it has been reported that COVID-19 has been used as a basis for seeking the suspension or lifting of pre-trial detention in the Netherlands on the grounds of its impact on prison conditions and in prolonging the length of investigations. ${ }^{37}$ Overall, it is not clear what effect the pandemic has had in this area but it may have added to the reasons why it is such a pressing candidate for fundamental reform in many European jurisdictions.

\section{Discussion of Norms and/or Policies of a European Origin}

At the European level, the EU and the Council of Europe, together with their agencies, bodies and institutions, have made their own contributions in the field of criminal law and justice during the course of the pandemic. Although not true of all of them, much of their activity might be classed as pedestrian in the sense that it is consistent with the sorts of reactions that might have been expected in the face of such an emergency. This is the case both with regard to criminal law enforcement and with regard to ensuring that the fundamental rights of suspects, defendants and offenders continue to be respected.

Dealing first with enforcement, Europol working in conjunction with other relevant EU agencies and the Council of Europe have issued warnings about the enhanced opportunities for cybercrime and other forms of COVID-19-related crime under the conditions of the pandemic. ${ }^{38}$ Added to this, both Europol and Eurojust have been involved in relevant operational investigations ${ }^{39}$ and, as mentioned earlier, Europol has published assessments of the impact of the pandemic on serious and organised crime. Complementing these activities, Eurojust has increased its support to national authorities with the aim of combating the disruption to criminal justice cooperation that has resulted from the imposition of measures to

\footnotetext{
$36 \quad$ Ibid.

37 de Vocht, 2 April 2020.

38 See 'COVID-19 Joint Statement' issued by Europol, ENISA (EU Agency for Cybersecurity), CERT-EU (the Computer Emergency Response Team and the European Commission, 20 March 2020; 'Cybercrime and COVID-19', Council of Europe News, 27 March 2020.

39 'Eurojust action against criminal groups abusing the corona crisis', Press Release, 8 April 2020; for Europol, see above. Some of this work has been in conjunction with other agencies, such as the EMCDDA.
} 
combat the spread of the virus. ${ }^{40}$ According to data that has been collated by the Council of Ministers, this support has been needed. During the first wave of the pandemic Member States' measures had a significant impact on the deployment of instruments such as the European arrest warrant; ${ }^{41}$ extradition to and from third States; the European Investigation Order; ${ }^{42}$ mutual legal assistance in criminal matters; and the framework decisions on the transfer of sentenced prisoners, freezing orders, confiscation orders and Joint Investigation Teams. ${ }^{43}$ Although the situation had been improving during the summer, ${ }^{44}$ it may have deteriorated more recently due to the imposition of fresh measures to address the infection's second wave.

Turning to the protection of fundamental rights in criminal justice settings, the concern has been that many of the preventative measures that European States have imposed are liable to have a detrimental impact upon the enjoyment of the rights that are afforded by the European Convention on Human Rights, the EU's Charter of Fundamental Rights (where it applies) and related instruments. Accordingly, the focus of attention for relevant European bodies has been on how to ensure that pertinent guarantees continue to be respected while enabling criminal justice to be practised safely.

40 See 'Eurojust remains fully operational during coronavirus crisis: Undiminished support for national authorities in the fight against cross-border crime', Eurojust Press Release, 3 April 2020; 'Eurojust action against criminal groups abusing corona crisis', Eurojust Press Release, 8 April 2020 https://www.ejn-crimjust.europa.eu/ejn/EJN_DynamicPage/EN/86.

41 Council Framework Decision 2002/584/JHA of 13 June 2002 on the European arrest warrant and surrender procedures between Member States (OJ $2002 \mathrm{~L}$ 190/1).

Directive 2014/41/EU of the European Parliament and of the Council of 3 April 2014 regarding the European Investigation Order in criminal matters (OJ $2014 \mathrm{~L}$ 130/1).

Council Framework Decisions 2008/909/JHA of 27 November 2008 on the application of the principle of mutual recognition to judgments in criminal matters imposing custodial sentences or measures involving deprivation of liberty for the purpose of their enforcement in the European Union (OJ 2008 L 327/27); 2003/577/JHA of 22 July 2003 on the execution in the European Union of orders freezing property or evidence $(\mathrm{OJ} 2003 \mathrm{~L}$ 196/45); 2006/783/JHA of 6 October 2006 on the application of the principle of mutual recognition to confiscation orders (OJ $2006 \mathrm{~L} 328 / 59)$ and 2002/465/JHA of 13 June 2002 on joint investigation teams $(\mathrm{OJ} 2002 \mathrm{~L} 162 / 1)$ respectively.

See 'The impact of COVID-19 on judicial cooperation in criminal matters - Executive summary of information compiled by Eurojust and EJN', 7693/2/20 REV 2, 26 June 2020; "The impact of COVID-19 on judicial cooperation in criminal matters - Executive summary of information compiled by Eurojust and EJN', 7693/3/20 REV 3, 18 September 2020. See also information compiled by the European Judicial Network: https://www.ejn-crimjust. europa.eu/ejn/EJN_DynamicPage/EN/86. For the impact on the justice field in general, see https://e-justice.europa.eu/content_impact_of_the_covidig_virus_on_the_justice_field37147-en.do?clang=en. 
Understandably in terms of their respective competences, the Council of Europe has tended to play a more dominant role here than the EU. Under its auspices, for example, the European Commission for the Efficiency of Justice has issued a Declaration that reminds courts and judicial authorities of the principles that they must continue to uphold despite the circumstances of the pandemic. ${ }^{45}$ And, in a separate initiative, the Council for Penological Co-operation Working Group has produced extensive guidance for prison authorities and probation services on dealing with the COVID-19 emergency while respecting human rights and the rule of law. ${ }^{46}$ Meanwhile, within the EU, the Fundamental Rights Agency has been collecting data on the situation in criminal justice settings as part of its broader project to monitor the fundamental rights implications of COVID-19. ${ }^{47}$

Moving away from these core matters, there is at least one dimension to the crisis, of relevance to criminal law, that has prompted responses from the EU and Council of Europe that might be regarded as more exceptional. It concerns the risk that the situation will disintegrate through a series of threats to democracy and the rule of law, as well as to human rights. Take the widespread imposition of lockdown and physical distancing measures as a starting point. It is beyond question that the consequence has been not only to deprive millions of people of rights and freedoms that had formerly been taken for granted but (as discussed above) to criminalise their exercise. Under normal circumstances, even a modest venture towards regulation of this character would be condemned as wholly unacceptable in the context of Europe's democratic societies, and with good reason. While the circumstances of the emergency provide an extraordinary objective justification for steps that have been taken, just how far does it extend?

45 Lessons Learnt and Challenges Faced by the Judiciary during and after the COVID-19 Pandemic, European Commission for the Efficiency of Justice Declaration, CEPEJ (2020)8rev, 10 June 2020.

46 COVID-19 Related Statement by the Members of the Council for Penological Co-operation Working Group of the Council of Europe, PC-CP (2020) 5, 17 April 2020. The guidance draws upon the Statement of Principles Relating to the Treatment of Persons Deprived of their Liberty in the Context of the Pandemic that was issued by the Committee for the Prevention of Torture and Inhuman or Degrading Treatment or Punishment (20 March 2020 Council of Europe News). See also 'COVID-19 pandemic: Urgent steps are needed to protect the rights of prisoners in Europe', Statement of the Council of Europe Commissioner for Human Rights, 6 April 2020.

See generally: https://fra.europa.eu/en/themes/covid-19. 
To understand the weight of the issues, it is instructive to consider the example of the so-called "rule of six" in England. ${ }^{48}$ In force from 14 September to 4 November 2020 , the rule restricted the number of individuals who were permitted to meet together, whether indoors or outdoors, to six. ${ }^{49}$ Breach of the rule was a crime, ${ }^{50}$ and attracted a fixed penalty notice of $£ 200$ (approximately $€ 220$ ) for a first offence, rising to a maximum of $£ 6,400$ (approximately $€_{7,010}$ ) for a sixth or subsequent offence(s). ${ }^{51}$ Expressly included in the restriction was the prohibition that individuals who belonged to one qualifying group of six must not "mingle with" any person who was not a member of that same group. This adoption of the concept "mingling with" has proved particularly controversial.

Defined in British English as "to move around and talk to other people at a social event" 52 or "to come into close association with", 53 critics argued that the phrase "mingling with" is too vague and uncertain to found criminal liability. Accordingly, they alleged that the rule was compromised in terms of legality. ${ }^{54}$ Adding fuel to the fire, on 15 September, the Home Secretary asserted that a chance meeting between two families of four, who then stopped for a chat

48 Different rules apply in the other constituent parts of the United Kingdom as health is a devolved competence. For further discussion of the rule of six see R. Fortson, "Mingling' and the 'Rule of Six' - What do the expressions "mingle" and "rule of six" actually mean?', 16 September 2020, https://www.qmul.ac.uk/law/research/centres-institutes/dol/cjc/ responding-to-covid-19/items/mingling-and-the-rule-of-six.html.

49 The rule was subject to specified exemptions and qualifications to accommodate households and support bubbles of more than six people. It was superseded by more onerous restrictions on 5 November 2020.

50 Health Protection (Coronavirus, Restrictions) (No.2) (England) Regulations 2020 (SI 2020/684), as substituted by the Health Protection (Coronavirus, Restrictions) (No.2) (England) (Amendment) (No.4) Regulations 2020, regulation 8(1).

$5^{1} \quad$ Health Protection (Coronavirus, Restrictions) (No.2) (England) Regulations 2020 (SI 2020/684), as substituted by the Health Protection (Coronavirus, Restrictions) (No.2) (England) (Amendment) (No.4) Regulations 2020, regulation 9(8). The fine levels were doubled, also by means of statutory instrument, on 24 September 2020: Health Protection (Coronavirus, Restrictions) (No.2) (England) Regulations $202 \mathrm{O}$ (SI 2020/684), as substituted by the Health Protection (Coronavirus, Restrictions) (No.2) (England) (Amendment) (No.5) Regulations 2020 (SI 2020/1029) (available at: https://www.legislation.gov.uk/ uksi/2020/1029/contents/made).

The Cambridge English Dictionary: https://dictionary.cambridge.org/dictionary/english/ mingle.

53 Collins English Dictionary: https://www.collinsdictionary.com/dictionary/english/mingle.

54 Article $7 \mathrm{ECHR}$, which is given force within the domestic legal order of the United Kingdom by the Human Rights Act 1998 . 
in the street, would constitute "mingling". ${ }^{5}$ Not only was there disagreement that her interpretation was correct but dismay at the idea that such innocuous behaviour might constitute a crime.

It is arguable that the underlying explanation for these problems lies with the method through which the rule was introduced. Rather than by Act of Parliament, the rule of six was established under regulations that were signed into law by a Government Minister by means of a statutory instrument (a form of secondary legislation). ${ }^{56}$ Use of this executive method of law-making meant dispensing with the normal legislative scrutiny that is applied to criminalisation decisions. With it went the potential opportunity to improve the precision of the rule. To make matters worse, the statutory instrument was not published until 11.30p.m. on 13 September, a mere 30 minutes before the new rule came into force.$^{57}$ It is also worth noting that it is not straightforward to track down or to understand, especially for an unqualified citizen. Therefore, compounding the difficulties with the substance of the rule, the mode of its introduction also paid scant regard for the principles of legality, such as fair warning.

This example may appear relatively trivial. None the less, it illustrates the potential for the extraordinary measures that have been adopted to address the COVID-19 crisis to undermine the values of democracy, the rule of law and human rights. Conscious of the long-term danger, the Council of Europe published a "toolkit" in April 2020 to assist its member states in ensuring that the values continue to be respected during the circumstances of the pandemic. ${ }^{8}$ It explains the requirements of Convention law in the context of emergency situations. Most of the core guarantees have a bearing on criminal law and justice and the document examines each in turn. It also includes

The Home Secretary is the Cabinet Minister who is responsible for interior affairs, including matters of law and order. Her remarks were made during a radio interview and can be heard here: https://www.bbc.co.uk/news/uk-54165362.

56 Health Protection (Coronavirus, Restrictions) (No.2) (England) Regulations 2020 (SI 2020/684), as substituted by the Health Protection (Coronavirus, Restrictions) (No.2) (England) (Amendment) (No.4) Regulations 2020 (SI 2020/986) (available at: https://www. legislation.gov.uk/uksi/202o/684/contents/made).

Its prospective imposition had, however, been announced by the Prime Minister during a press conference that took place on 9 September: https://www.theguardian.com/ world/2020/sep/og/coronavirus-rule-of-six-to-apply-in-england-from-monday.

$5^{8}$ Council of Europe, Respecting Democracy, Rule of Law and Human Rights in the Framework of the Covid-19 Sanitary Crisis: A Toolkit for Member States, Information Document SG/Inf(2020)11, 7 April 2020, page 2, available from: https://rm.coe.int/sg-inf2020-11-respecting-democracy-rule-of-law-and-human-rights-in-th/168ogenf4o (henceforth "Council of Europe Tookit, 7 April 2020"). 
an additional section on the specific topic of the protection of victims of crime.

The prospect that the COVID-19 crisis constitutes a threat to democracy and the rule of law has been troubling the EU too. The European Commission and the High Representative for Foreign Affairs and Security Policy, for example, have focused attention on the dangers that stem from an entirely different source. In June, they issued a Joint Communication on tackling COVID-19 disinformation. ${ }^{59}$ It was prompted by the so-called "infodemic" that has parasitised the pandemic; that is, the contagious spread of misinformation, disinformation, conspiracy theory and rumour relating to the origins of the virus, its diagnosis, treatment or cure and/or the legitimacy of official advice regarding its containment and management. As the Joint Statement records, this has had a bewildering array of pernicious effects, which, according to other research, include unnecessary deaths. ${ }^{60}$ Many of these effects are related to crime in one form or another. Having described the problem, the document examines the steps that have already been taken to address it and highlights some of the fundamental challenges that will need to be overcome in the further development of policy. They include the need to address the unchecked circulation of misinformation in the context of the wider concern to strengthen democracy.

Just as with the other dimensions to the Journal's scope that have already been discussed, there are plenty of questions to be asked regarding the respective contributions of the EU and of the Council of Europe in responding to the pandemic. For example, how adequate have the respective powers of these bodies proved to be in equipping them to tackle the criminal law and justice-related aspects of the COVID-19 crisis? And how effective have their interventions been in combating unwelcome consequences, such as opportunities for offending and disruptions to criminal justice cooperation?

59 European Commission and High Representative of the Union for Foreign Affairs and Security Policy, Tackling COVID-19 disinformation - Getting the facts right: Joint Communication to the European Parliament, the European Council, the Council, the European Economic and Social Committee and the Committee of the Regions, JOIN(2020) 8 final, 10 June 2020. On disinformation see also Europol, Catching the Virus: Cybercrime, Disinformation and the COVID-19 Pandemic, 3 April 2020, available at: https://www.europol.europa.eu/publications-documents/ catching-virus-cybercrime-disinformation-and-covid-19-pandemic.

6o Academic researchers have estimated that, globally, at least 800 people died as a result of misinformation relating to the virus during the first three months of 2020 and nearly 6 ,ooo were hospitalised: M.S. Islam et al, 'Covid-19-related infodemic and its impact on public health: A global social media analysis' (2020) The American Journal of Tropical Medicine and Hygiene: http://www.ajtmh.org/content/journals/10.4269/ajtmh.20-o812;jsessionid=ETrfB 53 Hw7 IIHnlp2BbSu4i.ip-10-241-1-122. 
Conversely, does the experience of recent months suggest that the available mechanisms to safeguard fundamental rights have proved resilient in the face of the emergency situation? If not, is this because of deficiencies in the mechanisms themselves or because States have used the crisis as an opportunity to sidestep guarantees? And, perhaps most fundamentally, what will be the lasting impact of the pandemic as far as the European way of doing criminal justice is concerned, located as it is in the shared values of democracy, respect for the rule of law and for human rights? As the Council of Europe's toolkit observes, "The virus is destroying many lives and much else of what is very dear to us. We should not let it destroy our core values and free societies." ${ }^{\prime 1}$

\section{Contributions to Criminological Debate in Europe}

In reaction to the pandemic and/or the measures that have been take to combat it opportunities abound for work that contributes to the criminological debate in Europe. For convenience, they can be divided into two categories.

First, there is the potential to apply a criminological perspective in investigating the impact on matters of crime, criminal law and related regulation, criminal justice, punishment and so on. Building on the discussion elsewhere in this editorial, examples include: detailed examinations of the types and patterns of offending and victimisation that have been associated with the crisis; analyses of their implications in terms of discrimination, inequality and power relations; evaluations of the COVID-secure methods of working in criminal justice institutions and their impact on the right to a fair trial; and assessments of the COVID-secure adjustments to prison and other punishment regimes and their consequences for offenders, their families and prison personnel. But the possibilities do not stop there.

For instance, contrasting with the focus on COVID-fomented crime, at an aggregate level, there is data to suggest that the imposition of lockdown regimes led to an overall drop in crime levels, at least temporarily. Take, for example, the UK Office for National Statistics (ONS). In August 2020, it published a statistical bulletin that contained a preliminary assessment of the impact of Covid-19 on crime and perceptions of crime in England and Wales during April and May. ${ }^{62}$ This was the period during the first wave of the pandemic when the

$61 \quad$ Council of Europe Tookit, 7 April 2020, page 2.

62 Office for National Statistics, Coronavirus and Crime in England and Wales: August 2020, 26 August 2020 (available at: https://www.ons.gov.uk/peoplepopulationandcommunity/ crimeandjustice/bulletins/coronavirusandcrimeinenglandandwales/august2020). 
strictest national lockdown restrictions were in place. On the basis of its data, the ons estimates that, with the exception of fraud and computer misuse, total crime fell by $32 \%$ as compared with a pre-lockdown two-month average. To quote: "Reductions were seen across many types of crime", but there were "significant falls in theft offences, particularly domestic burglary and other theft of personal property." And it explains that "this reflects the increase in time people spent at home during the lockdown period, a reduction in opportunities for theft in public spaces and the closure of the night-time economy."63

This phenomenon is far from unique to England and Wales: similar observations have been made regarding the position in other European states. They surface, for example, in the SPACE report that was referred to earlier. What makes this study particularly interesting is that it covers jurisdictions that have taken materially different approaches to combating the virus, including Sweden, which has been an outlier in declining to impose a national lockdown. As a result, the authors were able to take account of circumstantial comparative evidence to inform their view. ${ }^{64}$ All in all, therefore, there is reason to suppose that the pandemic is having complicated consequences for crime across Europe. ${ }^{65}$ Moreover, they are likely to continue for the foreseeable future bearing in mind the depth and scale of the economic shock that is already resulting from it. Through their study, much should be learnt that is of value to the pursuit of criminological debate in Europe.

Switching to measures to control the virus, another area that has not featured in the discussion so far is the extent to which they have relied upon strategies that involve mass surveillance and data gathering in conjunction with extreme restrictions on free movement. Regarded from this perspective, an obvious issue to explore concerns the contribution of the pandemic towards the rise of the security state. Rather than its criminogenic or criminal justice impact, which may have credentials as a moral panic, this may be the more significant lasting consequence of the developments of recent months. Like the macro effects on crime rates, criminologists have significant expertise to bring to bear here.

The second category of opportunities arises from the abrupt and dramatic transformation of the social and economic environment that has been effected by the imposition of lockdown and other measures to contain the virus: the

\footnotetext{
63 Ibid, page 2.

64 See, for example, Aebi and Tiago, 18 June 2020.

65 For a further illustration see M. Taylor, 'Did Covid-19 coronavirus lockdown laws just arrest European road deaths?', Forbes Media, 9 July 2020 (https:/www.forbes.com/sites/ michaeltaylor/2020/o7/og/did-covid-19-lockdown-laws-just-arrest-european-road-deaths/).
} 
so-called "new normal". Tangentially, this has created a form of natural laboratory by instituting a set of conditions that would usually be impossible to achieve and which might be exploited for the purposes of empirical investigation. On the one hand, there is scope for research questions that involve comparison between the pre-COVID, pandemic and, in due course, post-COVID environments. A detailed examination of the factors that promote or inhibit the commission of a particular form of crime or evaluation of adaptations to policing or the conduct of criminal proceedings might be structured in this manner, for example. On the other, by dint of the fact that these novel conditions have been instituted there are opportunities to pose research questions and/or investigate phenomena that would otherwise simply not arise. Regarded in this way, the pandemic affords a (hopefully!) unique chance to advance criminological knowledge, understanding and debate.

Take the field of compliance, for instance. The imposition of lockdown and other restrictions to quell the spread of COVID-19 can be understood as a series of mass experiments in inducing populations to abide by unprecedented and comprehensive restrictions upon their freedoms and liberties. Regarded as such, they present a fortuitous opportunity to evaluate the extent to which experience on the ground bears out the theoretical understanding of the mechanisms of compliance that has been achieved in recent years. ${ }^{66}$ Not only that, but there is also a further opportunity to enrich that understanding through detailed investigation of the variables that appear to affect compliance with (or, conversely, resistance to) lockdown rules, including how they have changed as the lifetime of the emergency has stretched. ${ }^{67}$ So too the interaction between compliance and other concepts in which criminologists are interested. These might include community cohesion and solidarity; culture; emotion; legitimacy; risk and insecurity; and trust, to name but a few.

A second illustration concerns the question of whether the experience of living under lockdown conditions might carry implications for public attitudes. In the ordinary course of events the sorts of deprivations that European states have imposed on their populations in recent months would be considered to be consistent with the institution of punishment, and of quite a draconian kind. In the interests of protecting public health people have been denied the right freely to see family members, to socialise with friends, to participate in

66 See, A.E. Bottoms, 'Morality, crime, compliance and public policy' in A.E. Bottoms and M. Tonry (eds), Ideology, Crime and Criminal Justice: A Symposium in Honour of Sir. Leon Radzinowicz (Willan, 2002).

67 Anecdotally, for example, it is often alleged that those in younger age groups are less willing to obey lockdown restrictions than those who are older. 
sport and other leisure activities, to attend religious gatherings and celebrate religious festivals in the usual way and/or to move and travel at will. More seriously still, under the strictest lockdown regimes, they have been compelled to live under conditions that are little short of house arrest. All-in-all, it is surely the case that, for many, the experiences of recent months are the closest that they are likely to come to finding out at first hand what it is like to be subject to a term of imprisonment or other highly restrictive punishment. Furthermore, even where the objectives of such measures are respected, it is likely that a significant proportion will have felt them to be punitive in their effects. On the face of it, this raises some intriguing questions concerning the potential to affect sensibilities in a manner that might have a material and lasting impact on public understanding of, and attitudes to, punishment.

\section{Closing reflections: Has the Crisis Really "Changed Everything”, or Will it Do So?}

Nobody can be anything other than acutely aware of the tragic death toll that is resulting from the spread of COVID-19. Sadly, one of those to have lost their lives is the British criminologist, Roger Matthews. ${ }^{68}$ Together with Dainis Ignatans, Roger co-authored the article 'Immigration and the Crime Drop' that the Journal was privileged to publish in 2017. ${ }^{69}$ As it bears out, one of the characteristics of Roger's academic work, for which we are in his intellectual debt, was his willingness to challenge orthodoxy and critically to scrutinise the assumptions upon which it is based. By way of tribute, it seems fitting to conclude this editorial with some brief reflections that endeavour to assume a similarly provocative spirit.

The title of the editorial refers to COVID-19 as "the crisis that changed everything",70 but is that characterisation deserved? On the basis that the pandemic has caused comprehensive disturbance to every aspect of daily life, on a global scale, and with consequences that will extend into the foreseeable future, the verdict must surely be yes. And, as the discussion above has sought

68 An obituary can be found here: https://www.theguardian.com/law/2020/apr/21/ roger-matthews-obituary.

69 See Volume 25(3) at pages 205-229.

70 It was inspired by an article in the Guardian newspaper: M. Safi, L. Kuo and P. Wintour, 'A world in lockdown: The crisis that changed everything', Guardian, 8 April 2020, available at: https://www.theguardian.com/world/ng-interactive/2020/apr/o8/ coronavirus-10o-days-that-changed-the-world. 
to show, that is as true of the sphere that is defined by the Journal's aims and scope as it is of other areas of activity. Across Europe, crime, criminal law, criminal justice and criminology have changed, or can be expected to do so, in reply to the evolutions in environment that the spread of the virus has brought with it. This, though, is not the only way of seeing things.

Reflecting on the events of recent months, it is possible to be struck, not by how much has changed, but by how little. In many respects, the developments that have been outlined here represent a continuation of the established practices and approaches that went before, albeit adapted to the new circumstances. Regarded from that perspective, the crisis is not in fact causing fundamental change. Moreover, it is arguable that there is comfort to be derived from that in the light of the understandable yearning to return to ways of life that used to be consumed as "normal". ${ }^{11}$ But that does not mean that the crisis lacks the potential to catalyse change.

Directing attention to places other than those that have been investigated so far, there are other stories of criminal law and justice to tell: stories that cast a spotlight on many of the more unpalatable and damaging aspects of how our societies are organised and the need for those aspects to be addressed. For instance, reference was made in passing to the pattern of unequal exposure and susceptibility to the virus and its relationship to factors of structural disadvantage. Looking more fully at that now, scientific evidence is accumulating to suggest that inhabiting poor, overcrowded housing; working in substandard, unregulated places of employment; and exposure to poor air quality are all critically linked to its spread and are inter-connected with its disproportionate impact on BAME communities. ${ }^{72}$ All three of these areas, and certainly the latter two, are ones that are of concern to the criminal law. Crucially, however, they have a profile that tends to downplay their importance in terms of harm and moral wrongdoing. What the pandemic shows up in sharp relief is that, if they are not tackled with commensurate energy to that which is expended in

$71 \quad$ ForanexamplethatistopicaltotheJournal,seeE.Brockes, 'Whencrimereportsseemlikearelief', Guardian, 8 August 2020, available at: https://www.theguardian.com/commentisfree/2020/ aug/o7/in-the-shadow-of-covid-new-yorkers-are-discovering-new-anxieties.

See, for example, 'Coronavirus: Virus outbreaks push Germany to clean up abattoirs', BBC News online, 20 May 2020, available at: https://www.bbc.co.uk/news/worldeurope-52738356; D. Carrington, 'COVID-19 rates in BAME groups linked to poor housing and air quality', Guardian, 20 July 2020, available at: https://www.theguardian.com/ world/2020/jul/19/covid-19-impact-on-ethnic-minorities-linked-to-housing-and-airpollution; D. Carrington, 'Air pollution increases COVID-19 death rate, large ONS study finds', Guardian, 14 August 2020, available at: https:/www.theguardian.com/world/2020/ aug/13/study-of-covid-deaths-in-england-is-latest-to-find-air-pollution-link. 
combating other forms of crime, the adverse consequences for wider society, as well as the direct victims, may be dramatic.

The reference to air quality also raises a second story, one that traces the connections between the pandemic and human degradations of the environment. Added to the contribution of air pollution in aggravating the infection is the generation of huge quantities of single use plastic waste as a result of the proliferation in use of PPE and which will take hundreds of years to biodegrade. The links begin, though, with what is believed to have been the pandemic's triggering event, when the virus jumped species (probably from bats) to infect human beings in China. Scientists have found evidence that environmental destruction and intensified farming play an important part in creating the conditions for such occurrences and warned of the potential for further pandemics to occur if these contributory factors are not addressed..$^{73}$ Once again, criminal law plays a role in regulating all of these environmental dangers but, here too, the seriousness and moral wrongfulness of the harms that it is intended to address tend to be downplayed. This is despite the scale of their potential impact, both in terms of current global reach and the deleterious consequences for future generations.

These are only two examples but what they serve to illustrate is that the COVID19 emergency is not merely one of public health but one in which many other spheres of life are implicated. If the pandemic truly is to "change everything", and change it in a positive direction, it is imperative that its more uncomfortable lessons are taken on board. In other words, as others have observed, "normal is the problem". Rather than wishing for a return to what we had before, we should aspire to something better. In the context of the Journal the challenge therefore is to contribute to the debate about what that future should be with respect to the matters that fall within its scope and how to bring it about.

\author{
Estella Baker \\ Professor of European Criminal Law \& Justice, Leicester De Montfort \\ Law School, De Montfort University, UK \\ ebaker@dmu.ac.uk
}

73 See, for example, R. McKie, 'Rampant destruction of forests will unleash more pandemics, warn scientists', Observer, 30 August 2020, available at: https://www.theguardian.com/ environment/2020/aug/3o/rampant-destruction-of-forests-will-unleash-more-pandemics. See also the detection of a new strain of the COVID-19 virus that appears to emerged on mink farms spread to infect human beings in Denmark: J. Dalton, 'Coronavirus: WHO experts study risk of mink fur farms worldwide spreading virus to humans after Denmark mutation', Independent, 6 November 2020, available at: https://www.independent.co.uk/ news/health/covid-mink-fur-farm-denmark-virus-mutate-b1644684.html. 